Southern Illinois University Edwardsville SPARK

SIUE Faculty Research, Scholarship, and Creative Activity

7-25-2015

\title{
Strategic Behavior and Variation in the Supreme Courts Caseload over Time
}

\author{
Kenneth W. Moffett \\ Southern Illinois University Edwardsville, kmoffet@siue.edu \\ Forrest Maltzman \\ George Washington University, forrest@gwu.edu \\ Karen Miranda \\ George Washington University, kramsey@gwu.edu \\ Charles R. Shipan \\ University of Michigan - Ann Arbor, cshipan@umich.edu
}

Follow this and additional works at: http://spark.siue.edu/siue_fac

Part of the American Politics Commons, Courts Commons, Judges Commons, Law and Society Commons, and the Legislation Commons

\section{Recommended Citation}

Moffett, Kenneth W.; Maltzman, Forrest; Miranda, Karen; and Shipan, Charles R., "Strategic Behavior and Variation in the Supreme Court's Caseload over Time" (2015). SIUE Faculty Research, Scholarship, and Creative Activity. 10.

http://spark.siue.edu/siue_fac/10

This Article is brought to you for free and open access by SPARK. It has been accepted for inclusion in SIUE Faculty Research, Scholarship, and Creative Activity by an authorized administrator of SPARK. For more information, please contact gpark@siue.edu. 


\section{Cover Page Footnote}

This is an Accepted Manuscript of an article published by Taylor \& Francis in Justice System Journal on July 25, 2015, available online: http://dx.doi.org/10.1080/0098261X.2015.1067156 


\title{
Strategic Behavior and Variation in the Supreme Court's Caseload over Time
}

\author{
Kenneth W. Moffett \\ Department of Political Science \\ Southern Illinois University Edwardsville \\ 0415 Peck Hall, Box 1453 \\ Edwardsville, IL 62026 \\ kmoffet@siue.edu \\ Forrest Maltzman \\ Department of Political Science \\ George Washington University \\ 440 Monroe Hall \\ 2115 G Street, NW \\ Washington, D.C. 20052 \\ forrest@gwu.edu \\ Karen Miranda \\ Department of Political Science \\ George Washington University \\ 440 Monroe Hall \\ 2115 G Street, NW \\ Washington, D.C. 20052 \\ kramsey@gwu.edu \\ Charles R. Shipan \\ Department of Political Science \\ University of Michigan \\ 5700 Haven Hall \\ 505 South State Street \\ Ann Arbor, MI 48109-1045 \\ cshipan@umich.edu
}

June 23, 2015

Our biggest thanks go to Robert Franzese and Paul Kellstedt for their invaluable and patient guidance on estimating our model. We also thank Sean Farhang, Grete Graf, Brian Harward, Luke Keele, and the anonymous reviewers for helpful comments and suggestions. Finally, we thank Michael Bailey, Tom Clark, and Keith Whittington for data. Shipan acknowledges the support of the United States Studies Centre at the University of Sydney. 


\begin{abstract}
Over the past sixty years, the size of the Supreme Court's docket has varied tremendously, growing at some points in time and shrinking at others. What accounts for this variation in the size of the docket? We focus on two key strategic factors - the predictability of outcomes within the Court, and whether justices consider the potential actions of other political institutions - and assess whether these factors help to explain the variation in docket size over time. We discover that uncertainty and institutional constraints prevent the Court from choosing cases with complete freedom, even after accounting for other potential influences on the size of the Court's docket.
\end{abstract}

Key Words: Judicial Decision Making, Separation of Powers, Supreme Court, Congress 
The size of the Supreme Court's docket has exhibited marked variability over time. At some points, such as between the mid-1960s and the mid-1970s, the docket increased in size. At other times, it decreased, with a low of 69 cases in 2007 prompting consternation among Court watchers. ${ }^{1}$ Even when the size of the docket has not exhibited either a steady increase or a steady decrease over a period of years, it has shown some notable year-to-year volatility.

Surprisingly, however, other than some recent attention from journalists and legal scholars - and one recent analysis by political scientists that we discuss below and throughout this paper - the aggregate size of the Court's docket has received little attention from social scientists and rarely has been subjected to rigorous empirical examination. We address this gap by focusing on a strategic explanation for the variation in the size of the Court's docket. This explanation suggests that justices themselves are strategic actors and that variation in docket size reflects the calculations that they make.

Their calculations are based upon two key considerations. First, docket size may reflect uncertainty within the Court about the eventual outcomes when it hears cases. That is, justices may accept fewer cases because they do not want to risk granting certiorari (hereafter cert) when the outcome within the Court itself is uncertain, and they may accept a higher number when they are more confident that they can predict outcomes. Second, the size could depend on the Court's view of other political institutions, with the Court less likely to hear cases when its views are at odds with those of the other branches. After controlling for a variety of non-strategic factors that may potentially influence docket size, we find that the Court strategically considers these factors when constructing its docket.

Our approach builds on Owens and Simon's (2012) recent and insightful examination of the size of the docket. To our knowledge, theirs is the only other study that has systematically explored potential

\footnotetext{
${ }^{1}$ In a 2007 Time article entitled "The Incredibly Shrinking Court," Von Drehle (2007) noted that while the citizens of the United States are the world's most prolific litigators, "our lawsuits aren't sexy enough to interest the Justices of the Roberts Court. We're not that into them, and they're not that into us." The issue's cover went so far as to pose the question, “Does the Supreme Court Still Matter?" See also Starr (2005-2006) and Chandler and Harris (2010).
} 
explanatory factors in a multivariate framework. Our analysis follows the trail that they have broken, but with several noteworthy differences. First, we consider the potential effects of other institutions, which allows us to focus on not only the internal factors that both we and they identify - namely, uncertainty about eventual outcomes - but also external factors. Thus, our analysis contributes to the literatures on both strategic behavior within the Court and strategic behavior with respect to other political institutions. Second, we explore a wider range of measures that capture uncertainty. Like Owens and Simon (2012), we find evidence of internal strategic behavior, with the Court less likely to hear more cases when justices are less certain about the outcome; but we also find that such evidence is inconsistent across a range of measures that credibly capture uncertainty. Third, we include a wider range of contextual factors that other scholars have identified as important influences on docket size, but that Owens and Simon did not incorporate into their analysis. And finally, we utilize a methodological approach that allows us to more appropriately account for the time-series nature of the data.

\section{The Supreme Court's Docket Since 1946}

Figure One displays the size of the Court's docket by term from 1946 through 2009. This figure demonstrates that variation in the number of cases the Court hears each term is not new. ${ }^{2}$ Nor is the current smaller docket size unprecedented - in 1953, for example, the Court heard 85 cases, only a handful more than the Court has heard in recent years. Before 1953, the number of cases was as high as 140 in 1946 and as low as 91 in 1951. Beginning in 1953, the number of cases increased and then leveled out, increasing again in the early 1970s. Then, throughout the 1970s and into the late 1980s, the Court heard about 150 cases per term, a figure that gradually dropped until the Court was consistently accepting fewer than 80 cases for review each year from 1998 onward. Overall, then, docket size exhibits four general trends: a decrease between 1946 and 1953; an increase between 1953 and 1971; a decrease starting in 1987; and annual volatility.

\section{[FIGURE ONE ABOUT HERE]}

\footnotetext{
${ }^{2}$ Later we discuss in more detail how we measure docket size.
} 
Why Study the Docket?

Why should we care about the size of the Court's docket? To begin with, variation in the size of the Court's docket stems from fluctuation in the size of the Court's discretionary docket. In this way, variation reflects the decisions that the justices make, so examining the factors that influence docket size provides an opportunity to understand decision-making on the Court.

Of course, it may be that the variation in caseload is a function of demand. Figure Two, however, makes it clear that this is not so. Although docket size has fluctuated, the number of cases submitted to the Court for review has steadily increased. In 1946, there were about 1,300 petitions for review. The number of petitions then rose incrementally for two decades, leveled off somewhat throughout most of the 1970s and 1980s, and then increased dramatically starting in the late 1980s, exceeding 10,000 in 2006. Despite this significant and generally monotonic trend, however, the Court's docket has not responded accordingly. Fluctuations in docket size appear to be largely unrelated to the number of petitions submitted to the Court; indeed, the correlation between these two variables is negative $(r=-.32)$.

\section{[FIGURE TWO ABOUT HERE]}

Beyond helping us understand judicial decision-making and allowing us to assess whether justices behave strategically, there are several other reasons why it is crucial to understand why docket size has varied over time. ${ }^{3}$ Some of these reasons are positive, while others are normative; some have been highlighted by judicial and legal scholars, while others have been raised by the justices themselves. Our point in raising these reasons is not to test them, but to justify why it is vital to understand temporal changes in docket size.

\footnotetext{
${ }^{3}$ In this section, we draw upon the excellent discussion in Owens and Simon (2012). See their more detailed discussion regarding the importance of this topic, which also identifies and explores a number of other justifications that we do not include (e.g., larger dockets allow a broader range of interests to be represented, while smaller dockets may allow certain interests to have excessive influence).
} 
To begin with, the number of cases the Court hears each term can be taken as an indicator of the justices' workloads. During the Burger Court, the justices' increasing workload became such a concern that some participants and observers recommended the creation of a national court of appeals $\left(\mathrm{O}^{\prime}\right.$ Brien 2005). In 1987, Baker and McFarland (1987) estimated that each justice read over 400,000 pages of written documents and spent over 800 hours writing opinions, attending conferences, and hearing oral arguments each term. Such an unmanageable workload has a host of negative repercussions for the Court's work, including "fragmented majorities, separate opinions, and sometimes even inadequate analysis" (Baker and McFarland 1987, 1401). Some justices agreed that the Court was overworked. In his 1984 year-end report, Chief Justice Burger explained that the "Justices must now work beyond any sound maximum limits" (Baker and McFarland 1987, 1400). ${ }^{4}$

In addition, docket size may also be viewed as a sign of the scope of the Court's influence. Rightly or wrongly, many assume that the Court "matters" more when it has a larger docket, and less when it hears fewer cases. In fact, some claim that the Court abdicates its duty when the size of the docket is too small (Hellman 1996). In part, this is because the Court isolates itself by not using its supervisory authority. And, in part, it is because as the Court takes fewer cases, important legal issues may be overlooked, leaving gaps in doctrine and a shortage of precedent.

Finally, the size of the docket has implications for the proper role of the Court. On one hand, some view it as the Court's obligation to hear and address cases to provide consistency across circuits (Baker and McFarland 1987). By hearing more cases, the Court can provide national unity, reduce jurisdiction, reduce the likelihood of judicial error by the lower courts, and so on (Hellman 1996). On the other hand, several justices have argued that a low caseload reflects the Court's proper role in the American judicial system. The Court, according to this view, was never meant to be a common-law court that rectifies every error in the lower courts. Justice Scalia (1987), for example, explained that the Court should not "gradually clos[e] in on a fully articulated rule of law by deciding one discrete fact situation

\footnotetext{
${ }^{4}$ But see also Brennan (1973) and Black (1974).
} 
after another." Rather, the justices need to "tolerat[e] a fair degree of diversity" in the manner rules are applied across the nation (Hellman 1996, 430). Justices Rehnquist and Ginsburg similarly expressed that they do not need to take each interesting case that comes before them, even if they believe it was decided incorrectly; and Justices Kennedy and Souter told the House Appropriations Committee that enough precedent was being established to guide the nation's judiciary through conflict (Hellman 1996). ${ }^{5}$

Clearly, then, there are significant reasons why understanding variation in the size of the Court's docket is important, reflecting both the potential effects of docket size and normative views about the role of the Court. In addition, investigating the factors that affect docket size allows us to make inferences about the extent to which strategic concerns influence the Court's actions. In the following sections, we provide a theoretical argument about how strategic factors affect docket size, outline our hypotheses regarding these strategic considerations, and discuss other factors that have been identified as potentially influencing docket size.

\section{Strategic Considerations and the Variation in Docket Size}

Like all political actors, justices can make strategic calculations when deciding whether to act. These calculations inevitably consider constraints that stem from the potential actions of both their brethren on the bench and by actors outside of the Court. Broadly speaking, then, strategic behavior on the Court can take two forms: internal and external. The importance of both internal and external constraints in shaping judicial decisions has been recognized for decades (e.g., Murphy 1964), and has been the focus of recent work on judicial decision-making in both the US (Bailey, Maltzman, and Shipan 2011) and abroad (Ferejohn, Rosenbluth, and Shipan 2007).

To behave strategically, though, political actors need a context that facilitates such behavior. We contend that the process by which cases reach the Court provides this context. In the next section, we describe this context and identify how it facilitates strategic behavior. Following that, we address the two

\footnotetext{
${ }^{5}$ Chief Justice Rehnquist also stated that the Court simply cannot review all decisions where conflict exists (Baker and McFarland 1987).
} 
types of strategic behavior that justices might engage in with respect to filling the docket, focusing first on internal considerations and second on external considerations.

\section{Context for Strategic Behavior: Supreme Court Case Selection}

When a party in a lower court case loses, it has the option to appeal the decision that was made to the Supreme Court. The primary route by which to do this is to file a petition for a writ of certiorari with the Court. Before Chief Justice Burger created the cert pool in the early 1970s, each justice (with his clerks) examined every case and began the case selection process by eliminating those cases that obviously lacked merit or lacked a set of "good facts" (see Perry 1991). ${ }^{6}$ When the cert pool was created, justices who participated effectively delegated part of this process to a pool of law clerks, one of whom would be randomly selected to write a brief memoranda about each case (Palmer 2001). Justices who participated could then draw upon these memoranda to decide which cases merited further review.

From here, the Chief Justice creates the "discuss list," which comprises those cases that are considered worthy enough to be discussed at conference for discussion and voting (Stern, Gressman, Shapiro, and Geller 2002). Associate justices can add petitions to this list that they think the Court should consider. Based on the outputs of these earlier stages, including the cert pool, the Chief Justice's discuss list, and the addition by associate justices of petitions to be discussed, the justices then vote on which cases to hear.

From the standpoint of understanding changes in docket size over time, this process of deciding which cases to hear has four key features. First, justices have discretion about which cases to hear, with the freedom to vote in favor of cases they want to hear and against those they want to avoid. Second, they do not need to provide any reasons for opposing cert. Third, they conduct this process largely away from public view, which is especially important from the standpoint of considering external influences. Finally, the process provides them with additional information about the views and opinions of their colleagues.

\footnotetext{
${ }^{6}$ According to Brennan (1973), over $90 \%$ of in forma pauperis petitions lacked merit.
} 
Taken together, the features of this process thus provide justices with an ideal opportunity to behave strategically when deciding which cases to hear. Before and after the creation of the cert pool, the process provides justices with ample opportunity to exercise judgment, to make carefully calculated and informed choices about the size and content of the Court's docket, and to do so in a private process. ${ }^{7}$ In the following sections, we argue that the size of the Court's docket results from the combination of the strategic opportunities that arise from this process with the internal and external considerations that affect justices' strategies and choices.

\section{Internal Considerations: Uncertainty within the Court}

Internal strategic behavior occurs when justices adapt their behavior in anticipation of the preferences and behavior of their colleagues. The idea that justices engage in this sort of strategic behavior is well established in the judicial politics literature, beginning with Murphy's (1964) pioneering analysis and continuing through a wide range of case-oriented and statistical tests (e.g., Maltzman, Spriggs, and Wahlbeck 2000; Epstein and Knight 1998). In particular, several studies have established that individual justices take uncertainty into account when deciding whether to grant cert. Caldeira, Wright, and Zorn (1999) demonstrate that justices vote strategically when deciding whether to hear cases, taking into account the ideological preferences of other justices, as well as uncertainty about the outcomes that are likely to result if the Court hears the case. Importantly, from our perspective, their evidence shows that these strategic calculations can affect the number of cases on the docket. Although their study is one of the richest theoretical explorations of internal behavior, several other studies have also provided strong theoretical and empirical evidence that individual justices behave strategically, taking into account ideology, uncertainty about potential outcomes, the views of the Solicitor General, and other factors (e.g.,

\footnotetext{
${ }^{7}$ We recognize that some (e.g., Starr 2005-2006) have argued that the creation of the cert pool has had the effect of reducing the number of cases the Court hears, partly due to the pressures it places upon clerks to recommend denying cert. In our view, the opportunity for justices to choose cases strategically does not depend on the existence of the cert pool. Still, we address the possibility that the creation of the cert pool might have produced a smaller docket size when discussing additional checks on our main results.
} 
legal considerations) when deciding whether to grant cert (e.g., Palmer 1982; Black and Owens 2009, 2012; Brenner and Krol 1989).

These studies identify the considerations that affect individual justices' cert votes. But the logic behind these studies, especially as related to strategic behavior and uncertainty about potential outcomes, also can provide insights into the aggregate size of the docket and how it varies over time (Owens and Simon 2012). Consider the decision of an individual justice who is trying to decide whether to vote in favor of granting cert to a case. This justice might be certain that colleagues share her views about the merits of the case; uncertain about their views; or certain that they will disagree with her. We consider each scenario below.

To begin with, if this justice is certain that at least four of her colleagues will agree with her views, and thus that her views will prevail, she is more likely to vote to hear the case. ${ }^{8}$ Thus, if the case concerns a lower court ruling and the justice agrees with that ruling, then greater certainty that her colleagues share her views increases the likelihood that she votes to hear the case. Doing so will likely result in affirming the lower court's decision and applying the outcome to the entire country.

The justice's certainty regarding her colleagues' views also can work in the opposite direction that is, she may be certain that their views differ from hers. In the example being used, then, she may be relatively certain that they will vote to reverse the lower court. In this scenario, the justice votes against granting cert, preferring that the Court not hear the case and instead wanting the lower court's decision to stand. This justice's views will not prevail because at least four justices - the ones whose views differ from hers - will vote in favor of granting cert. Thus, in this scenario, like the first scenario, the Court hears the case because her colleagues will likely vote to grant cert.

What if this justice is uncertain about how the other justices will vote? In this scenario, voting to hear the case becomes risky, because as she becomes more uncertain about how her colleagues might

\footnotetext{
${ }^{8}$ Stras $(2010,154)$, for example, notes that justices may consider "whether plenary review of the case is likely to result in an outcome or holding that is consistent with their ideological views."
} 
vote, she becomes increasingly leery of hearing the case. The logic is straightforward: even though she personally would like to affirm the lower court's ruling, her uncertainty about her colleagues' preferences - and the possibility that her colleagues might vote to reverse the lower court - means she will vote against cert, preferring to leave the lower court's decision in place for at least part of the country rather than having it reversed for the entire nation.

Importantly, the logic spelled out for this individual justice in the preceding discussion has aggregate-level implications. First, when uncertainty is low, there will always be enough votes to grant cert and to hear the case. With respect to our hypothetical justice, if she favors hearing the case because she is relatively certain that her colleagues share her views, then she (along with the others who share her views) will vote to hear the case. And since only four votes are needed to hear the case, it is likely that at least that many justices will vote to grant cert. But even if the justice is relatively certain that her colleagues do not share her views, the vote in favor of granting cert is still likely to be positive. Although our hypothetical justice will vote against granting cert (as will the other justices who share her views), a majority of justices will prefer the opposite outcome and votes to hear the case. Thus, when certainty is high, the Court will hear a higher number of cases.

Second, if justices are uncertain about how their colleagues will vote, they will be more hesitant to vote in favor of granting cert, with those who favor reversing the lower court fearing that others might vote to affirm, while those who want to affirm will worry that the others might vote to reverse. As a result, under high levels of uncertainty justices will be reticent to hear cases and the Court will hear fewer cases overall.

Consequently, the amount of uncertainty that justices have about the final outcome should affect the aggregate docket size. When uncertainty is low, the Court will hear more cases. On the other hand, when uncertainty is high, the Court will hear fewer cases. Notably, the process by which justices decide which cases to hear facilitates the possibility of such behavior. With respect to these internal considerations, it does so by providing justices with discretion about which cases to hear, as well as the 
opportunity to learn more about their colleagues' views. ${ }^{9}$ Thus, the effects of uncertainty can be tested at the aggregate level, leading to the following hypothesis:

H1 (Uncertainty Hypothesis): The Court will hear a higher (lower) number of cases as outcomes on the bench become more (less) certain.

\section{External Considerations: Separation of Powers}

In addition to internal considerations, numerous scholars contend that the Court is engaged in a separation-of-powers struggle with the executive and legislative branches (e.g., Murphy 1964; Ferejohn and Shipan 1990; Harvey and Friedman 2006; Maltzman, Mark, Shipan, and Zilis 2014; Whittington 2007). To the extent that this occurs, the Court considers the preferences of the other branches of government, since failure to do so might produce two types of negative consequences. First, if the Court reaches an outcome that runs counter to the preferences of the elected branches, those other branches might respond by proposing and passing new laws that decrease the policy utility of justices (Blackstone 2013). Second, the Court will be wary of other sanctions that Congress and the president may impose on the Court, such as decreased jurisdiction, lowered funding, reversing the policy effects of the Court's decisions, and so on (Shipan 1997; 2000).

Some scholars have argued that such sanctions have a limited effect on the actions of the Court (e.g., Segal 1997; Segal and Spaeth 2002). Other scholars, however, have found evidence that the Court considers potential congressional reactions when making decisions, even though such threats are not carried out frequently (e.g., Epstein and Knight 1998; Harvey and Friedman 2006; Blackstone 2013). Our argument recognizes that the existence of the threat can have an effect. Further, we contend only that the

\footnotetext{
${ }^{9}$ We cannot, of course, test whether justices obtain specific information relevant to their uncertainty during these closed conferences, or what type of information they receive. Thus, as we discuss in a later section, our tests rely on indicators of past behavior. What we can and do assume, however, is that the conferences provide justices with additional corroboration of this past behavior.
} 
Court is worried about any potential negative repercussions, regardless of the form that they may take, and that it will proceed more cautiously when it thinks such actions are more likely. ${ }^{10}$

This last point is worth elaborating. Given the huge volume of cases the Court is asked to hear each year, it would be impossible for justices to determine how Congress and the president might react on every single case. Even with the creation of the cert pool, which was designed to help justices deal with an increased workload, the Court lacks the capacity to consider the potential reaction of these other actors to each potential case. Instead, we argue is that justices are aware of how distant Congress and the president are from the Court in terms of ideology and policy preferences. When they are farther away, justices will proceed more cautiously and tread more carefully. When these other branches are closer and their preferences are more similar, the Court can act more freely, given the lower likelihood of negative consequences. Effectively, then, justices and their clerks - whether taking part in the cert pool or acting independently - will be on heightened alert when the Court's actions are more likely to trigger a negative reaction.

How might the potential for negative consequences when Congress and the president are more distant affect the Court? First, it might be insufficiently worried about the possibility that Congress might retaliate, or believe strongly enough in its views, that it will simply go ahead and decide to hear the case, throwing caution to the wind. Second, it might decide to hear this case, knowing that it can modify the final opinion so that the outcome satisfies at least one branch of Congress, thereby decreasing the threat of legislative retribution. Third, it might change the types of cases that it chooses to hear, thereby simply avoiding cases that will trigger negative reactions. Finally - and central to our argument - it might choose to avoid hearing cases that are likely to trigger negative reactions from other political actors.

Each of these scenarios is possible. But as long as the Court at least sometimes declines to hear a case because justices worry about potential repercussions, and as long as it does not always either modify

\footnotetext{
${ }^{10}$ Thus, the measure that we use below, which captures whether the Court's preferred policy lies within the Pareto set for elected national officials, can be seen as a proxy for whether the Court's action is likely to trigger a reaction.
} 
its decision or supplant this case with a less controversial one, then the Court will hear fewer cases as its preferences diverge from those of other political actors. ${ }^{11}$ Further, there are good reasons to expect this sort of behavior to occur. To begin with, evidence from case studies (e.g., Epstein and Knight 1998) and statistical analyses (e.g., Harvey and Friedman 2006; Blackstone 2013) indicates that the Court considers the potential for negative reactions and repercussions from Congress when reaching decisions on cases and when choosing to hear cases (e.g., Harvey and Friedman 2009). In addition, modifying decisions can be a risky proposition, as it might be difficult to determine exactly which outcome will stop just short of generating antagonism. Moreover, if the Court needs to modify the outcome, its gain in utility decreases such that it might no longer justify the overall costs associated with hearing a case. Finally, if the Court's views differ from those of Congress and the president on one issue, they are also likely to diverge on others.

Once again, the process by which the Court decides which cases to hear provides a good opportunity to strategically behave. The process provides justices with the discretion to decide which cases they want to hear, the freedom to avoid having to give a reason for their decision, and the ability to decide in private (which is especially important when dealing with potentially delicate inter-branch considerations). Again, justices need not consider the reactions of the other branches to every case. Rather, justices will be on the lookout for those cases that might cause problems and produce negative consequences. Thus, divergence between the Court's preferences and those of the elected branches should reduce the number of cases that the Court can hear without worrying about triggering a negative response. In turn, this should yield a decrease in the number of cases that the Court hears. If justices' preferred

\footnotetext{
${ }^{11}$ For example, Hendershot et al. (2013) explore whether the Court changes the types of cases that it hears over time in response to elected branch preferences. They find that the Court indeed does vary its attention to different issue types, depending on the preferences held by different branches. However, although changing the types of cases is one strategy that the Court can, and does employ, it is not the only strategy that the Court can use. Our argument holds if the Court utilizes the fourth approach we listed - avoiding hearing cases that might trigger a negative reaction - at least some of the time.
} 
outcomes run counter to the preferences of the elected branches, then they will choose to hear fewer cases. Our second hypothesis captures this view.

H2 (Separation of Powers Hypothesis): The Court is likely to hear more (fewer) cases when its policy preferences are similar to (differ from) those of the executive and legislative branches.

\section{Additional Influences on Docket Size}

To test our main hypotheses, we also need to consider other factors that might influence the size of the docket. Although many factors have been posited to affect docket size, we focus on several key indicators that other scholars, observers, and participants have identified. ${ }^{12}$ To begin with, some observers assert that the Court sees more opportunities to make policy when Congress and the president have been more active in passing laws. Greenhouse contends that "as Congress's willingness to pass new laws has waned, the flow of statutory cases has begun to dry up" (2006, A1). Justices themselves have promulgated this view, with Chief Justice Roberts citing the lack of major new laws as a significant cause of the drop in docket size (Coyle 2007). According to this view, the Court will hear more cases when Congress has enacted a higher number of laws, and fewer when Congress has been less active.

Policy preferences also might shape a justice's willingness to support granting cert. For many years, judicial scholars have suggested that justices act in a manner consistent with their policy preferences (Segal and Spaeth 2002). Similarly, some researchers also suggest that judges choose cases to overturn lower court decisions that are incompatible with their own ideologies (Baum 1977; Songer 1979). If true, the Court will take on more cases as ideological harmony between the Court and the lower courts decreases, and fewer when it increases (Owens and Simon 2012).

Institutional factors also might affect the size of the agenda. For instance, the Court gained the ability to shape its own docket in 1925, an ability that the 1988 Act to Improve the Administration of Justice modified. This Act, which almost completely eliminated the Court's nondiscretionary jurisdiction, led many members of the media and scholars to speculate that it might be a potential cause of the

\footnotetext{
${ }^{12}$ For a comprehensive list of potential causes, see Chandler and Harris $(2010,2)$.
} 
reductions in docket size observed during the 1990s (Barnes 2007; Greenhouse 2006; O’Brien 1997b, 2005). Some Supreme Court justices have concurred. In 1996, for example, Justice Kennedy explained to the House Appropriations Committee:

We had mandatory jurisdiction over cases that were unimportant. We calculated that there were 35 to 40 of these a year. We told the Congress, please take those cases away from us, and the Congress did. And in part what you see after 1988 is a drop which we projected (Hellman 1996, 409).

Indeed, Owens and Simon (2012) provide evidence that the 1988 Act has had exactly this effect.

Consequently, we expect that prior to 1988, the Court heard more cases, and after 1988, it heard fewer.

Including a dummy variable for the 1988 law is appropriate, especially given the attention that others have paid to the potential effects of this law, but it is a blunt institutional measure. A more nuanced approach is to consider broader changes in the Court over time. In particular, McGuire (2004) has argued that changes in the institutionalization of the Court have put justices in a better position to achieve their goals and that it has increased the Court's control over its agenda. As the Court becomes more institutionalized, it has a greater capacity to address issues it deems important. Thus, we expect that the Court will hear more cases as institutionalization increases.

A third institution that might influence the size of the Court's docket is the join-3 practice. Although since 1925 the process has required at least four votes to grant review for writs of certiorari the so-called Rule of Four - starting in the 1970s some justices announced that they would cast a vote to grant cert if three other justices did the same. When a justice embraces this approach, it effectively reduces the number of votes needed to grant cert from four to three, since that justice has indicated that whenever there are three justices who favor hearing a case, he or she will provide the necessary fourth vote. ${ }^{13}$ Since the casting of a join-3 vote can reduce the number of justices needed to grant cert, some

\footnotetext{
${ }^{13}$ There may be instances in which the justice who favors the join-3 practice is already one of three justices who have indicated that they would like to grant cert, in which case the justice's adherence to join-3 is irrelevant. But as long as there are other cases where this justice is not one of three justices who favor granting cert, adherence to this practice will increase the docket size.
} 
have proposed that the join-3 practice is linked to fluctuations in the Court's docket (O'Brien 1997a; 2005), with the Court likely to hear more cases when one or more of its members favor this practice, and fewer otherwise.

Many scholars also contend that the Court considers the preferences of other external actors. One such actor is the public. As Clark $(2009,2011)$ argues, public opinion is filtered through Congress, with negative opinion toward the Court leading legislators to introduce more court-curbing bills. Since these bills, if they were to become law, could potentially undermine the Court's legitimacy, justices will react to an increase in the introduction of court-curbing bills by becoming more cautious. Thus, the Court may hear fewer cases when it is faced with a larger number of court-curbing bills, and is free to hear more when it feels less threatened. ${ }^{14}$ Second, the Solicitor General (SG) may play a crucial role in determining docket size, with the Court much more likely to take cases when the SG is a petitioner (Cordray and Cordray 2001).

\section{Data}

To measure our dependent variable, the size of the Court's docket, we use the number of cases that receive plenary consideration per term. A case is considered part of the plenary docket if it was an orally argued, non-decree, non-memorandum case disposed of by either signed or per curiam opinion. ${ }^{15}$

\footnotetext{
${ }^{14}$ Clark (2011) demonstrates that the Court overturns fewer bills and adjusts its opinions when the public opposes the Court (as captured by the number of court-curbing laws introduced). He does not examine docket size; but given that his emphasis is on whether the Court behaves more cautiously, it is a reasonable extension to examine whether the Court hears fewer cases when it feels besieged. Of course, since the Court is also reacting to the actions of Congress, this could also be seen as another version of a separation of powers argument. However, Clark makes it clear that he uses court-curbing bills as a way to capture public unhappiness with the Court.

${ }^{15}$ Although Hellman (1996) argues that all orally argued cases, including those disposed of by per curiam opinions, fall under the plenary docket heading, he notes that other analyses count only signed opinions. We employ Hellman's (1996) definition, which comprises DEC_TYPEs 1, 5, 6, and 7 from The Original United States Supreme Court Judicial Database. Additional information was also obtained from the Chief Justice's Annual Report. If we
} 
Due to the availability of our independent variables, our analysis focuses on the 1946-2005 period.

\section{Measuring the Strategic Variables}

We coded several variables to assess our hypotheses about strategic behavior. To begin with, as the Uncertainty Hypothesis details, one might expect that a justice's willingness to support granting cert depends upon his or her certainty about the likely outcome of the case, should the Court decide to hear it. This certainty is contingent on two factors. First, it depends upon the stability of a winning coalition. If there are five like-minded justices who vote together consistently, members of the coalition are likely to assume that they will be part of the winning coalition. Conversely, if there is no dominant majority coalition, justices will decide on cert in the face of greater uncertainty about the eventual outcome (and the coalition supporting that outcome). In the former case, more justices are likely to vote for cert, leading to a larger docket.

To investigate the effects of the stability of winning coalitions, we identified the five justices who voted as a bloc most frequently during the previous term. We then calculated the percentage of each term's opinions that included these five justices. When this percentage is high, the winning coalition is stable and justices in that coalition are more certain about the Court's likely decision and also more convinced that they will be in the majority, making them more likely to vote to grant cert. Consequently, we expect that this variable, Stable Winning Coalition, will have a positive coefficient.

Second, a justice's level of confidence in the outcome depends on divisions within the Court. If the Court is evenly divided, then winning coalitions will be smaller. Such coalitions will yield more uncertainty about the outcome, since the switch of one or two justices can change the outcome. On the other hand, when winning coalitions are large and the Court is not evenly divided, the outcome is more certain, leading more justices to vote to grant cert. To capture this concept, we created a variable called Split Decisions, which is the percentage of cases in the previous term that were decided by a close or

instead use Owens and Simon's (2012) measure of the docket in place of our own, many of the results are similar to those we report here, although Stable Winning Coalition no longer achieves significance. 
"split" decision. We calculated this variable by dividing the number of 5-4 decisions by the number of cases on the Court's docket. We expect this variable to have a negative coefficient.

One potential problem with Split Decisions is that although a large number of 5-4 decisions might indicate uncertainty, the majority might not always consist of the same five justices. For example, there might be many 5-4 decisions, but if the same five justices always vote together, there is little or no uncertainty. ${ }^{16}$ Nonetheless, it is reasonably likely that the composition of votes on cases in a term might affect docket size in future terms. If all of the votes on a term's cases are ideologically connected, then there is no uncertainty surrounding the outcomes of cases. ${ }^{17}$ If, on the other hand, all of the votes on cases in a particular term are ideologically disconnected, then one would be more uncertain about the outcomes of cases. Thus, we expect that an increase in the percentage of votes on cases that are ideologically disconnected should result in fewer cases on the docket.

To measure this concept, we created a variable, Ideologically Disconnected Coalitions, which is the percentage of cases in the previous term that were decided by ideologically disconnected coalitions (Edelman, Klein, and Lindquist 2008). We used a three-step process to compute values for this variable. First, we used Judicial Common Space scores to measure the ideology of justices in each term. Second, we counted the number of cases in each term that were decided by ideologically disconnected coalitions. Finally, we divided the number of these cases by the total size of the docket.

\footnotetext{
${ }^{16}$ To assess whether this occurred, we examined the correlation between the percentage of 5-4 cases and the percentage of those cases in which the most common coalition of five justices voted together. We found little correlation $(r=.104)$, indicating that as the number of 5-4 cases increases, it is not that the same five justices are winning more frequently. Therefore, the percentage of 5-4 cases provides a reasonable, if rough, measure of uncertainty about case outcomes.

${ }^{17}$ A vote on a case is ideologically connected if at least five justices in the same ideological alignment vote in the majority on that case (see Edelman, Klein, and Lindquist 2008). For instance, if the five most liberal justices comprise the majority vote on a case, then that case is considered to be ideologically connected.
} 
To examine whether justices are sensitive to the Court's external political environment and whether they behave strategically with respect to this environment when deciding whether to hear cases, we created a variable called Supreme Court Outlier. Based on ideology scores computed by Bailey (2013), this dummy variable is set equal to one when the median Supreme Court justice's ideology is located outside of the range of preferences of the president and the median Senate and House members during the previous term, and zero otherwise. ${ }^{18} \mathrm{We}$ employ this measure because Congress needs the president's assent (and vice versa) to overturn the Court. We use this variable to test H2, the Separation of Powers Hypothesis, and expect a negative coefficient.

\section{Measuring Additional Influences}

In addition to our strategic variables, we also need to measure the control variables we identified earlier. To investigate whether the Court hears more cases when Congress has passed a higher number of laws, we use those laws that were deemed major when they were passed and that would have attracted the attention of other political actors at that time (Mayhew 2005). Although the Court can hear cases that challenge laws from any era, it frequently hears challenges to relatively recent laws (e.g., Dahl 1957). Hence, Major Laws consists of the sum of Mayhew's (2005) Sweep One laws passed within the previous four years. ${ }^{19}$

We created two variables to assess whether ideological harmony between the Supreme Court and the lower courts shapes docket size. The first measure, Judicial Agreement, is a binary variable that is coded one when the lower courts and the Court have similar preferences during the current term - more specifically, when the majority of the appellate courts are composed of Democrats (Republicans) and a

\footnotetext{
${ }^{18}$ These scores draw upon observations in which there exist "bridges" between members of Congress, the president, and the Court. These bridges include amicus briefs, comments by members of Congress, roll call votes by members of Congress, votes on Supreme Court cases by Justices, and cosponsorship (Bailey 2013).

${ }^{19}$ The results are nearly identical if we extend the time period to five or six years. The only difference is that the significance of Stable Winning Coalition drops slightly below the level of $\mathrm{p}<.05$.
} 
majority of Supreme Court justices are liberal (conservative). ${ }^{20}$ This measure should have a negative coefficient, indicating that the Court will hear more cases when it is generally disagrees with the lower courts.

The second measure, Supreme-Appellate Court Distance, is calculated as the absolute value of the distance between the Supreme Court median and the median appellate court during the current term, using Judicial Common Space scores (Epstein et al. 2007). This variable should have a positive effect, indicating that the more ideologically distant the appellate courts are from the Supreme Court, the more cases the Court will choose to hear.

To control for the potential effect of the 1988 Act on the Court's docket, we created a Post-1988 dummy, which we coded as one for years after 1988. If this Act produced a reduction in the number of cases, then we should observe a negative coefficient. To measure changes in the Court's capacity over time, we used McGuire's (2004) measure of institutionalization. We expect the coefficient on this variable, Institutionalization, to be positive. To ascertain whether changes in the tendency of justices to join-3 can account for the temporal changes in docket, we draw upon O'Brien's (1997b) argument that Blackmun was the most frequent, well-known supporter of this approach, and we created a dummy to denote the years in which Blackmun served on the Court. Although this measure is blunt, it captures the view that Blackmun was the justice who was most committed to casting join-3 votes. We expect this variable, Blackmun/Join-3, to have a positive sign.

We use two measures to measure the additional effects of other external influences. To capture the Court's concerns about its legitimacy, we used data from Clark $(2009,2011)$ on the number of courtcurbing proposals that the House and Senate proposed in the previous Congress. We used the previous term since it takes time for the Court to respond to such signals. Then, we logarithmically transformed this variable, since Clark $(2009,2011)$ posits that the relationship between Court reaction and the number

\footnotetext{
${ }^{20}$ We use Martin-Quinn scores to measure liberal and conservative, where median scores less than zero are liberal and those greater than zero are conservative.
} 
of court-curbing proposals that Congress proposes is non-monotonic. ${ }^{21}$ Finally, to ascertain whether variation in docket size is a function of the Solicitor General's interest in appearing before the Court, we created a variable, Solicitor General Petitions, that is the number of petitions filed by the SG during the current term. We expect a positive coefficient for this variable. ${ }^{22}$

\section{Analysis and Results}

Because our dependent variable is the change in the number of cases that the Court hears in each year, it is possible that the observations in our dataset are not independent of each other. The use of standard least squares techniques in such cases can produce spurious results, where relationships appear to be significant but actually are not (i.e., Type I error). Thus, we need to check for stationarity and autocorrelation to verify which estimation technique is appropriate for the data that we seek to analyze.

To check for stationarity, we begin with Figure One, which displays the number of cases that the Court hears each year. Although the data do not show evidence of a long-term, monotonic trend, it is also clear that the mean of the variable is not constant over time. This visual impression is supported by an augmented Dickey-Fuller (ADF) test, which fails to reject the null of a unit root $(\mathrm{p}=.70) .{ }^{23}$ Similarly a KPSS test, which treats stationarity as the null hypothesis, rejects the null in the first ten of fifteen lag orders. Thus, we cannot conclusively rule out the possibility of a unit root, since the results of our test are sensitive to the lag-order specification.

${ }^{21}$ More specifically, he argues that there exists a tipping point after which the Court responds to court-curbing bills. Therefore, we used the following formula to perform this transformation (Clark, 2009, 979):

$$
\text { Court Curbing }{ }_{t}=1 /\left(e^{-\frac{\text { Bills }}{2}}\right)-.5
$$

where Bills is the number of court-curbing bills introduced in either chamber during the previous two Congresses.

${ }^{22}$ We obtained this variable from the Annual Report of the Attorney General in each year.

${ }^{23}$ We also ran the Phillips-Perron test, which similarly did not allow us to reject the null for a unit root. In addition, a Durbin-Watson test indicates that our data show some evidence of autocorrelation. Although simply running a Koyck model would address the autocorrelation problem, such an approach is inappropriate when data are nonstationary (Keele and Kelly 2006). 
Given that the ADF test suggests the potential presence of a unit root and the KPSS test does not eliminate this possibility, the conservative approach is to use an error-correction model (ECM). Following De Boef and Keele (2008), we utilize the approach that is the most appropriate for non-stationary data and is also least restrictive in the constraints it implicitly places on that data. Thus, this model provides an appropriate econometric tool we can use to assess our hypotheses. It also allows us to learn whether our independent variables have a transitory (i.e., short-term) effect, an equilibrium-like long run (i.e., longterm) effect, or both. ${ }^{24}$ Finally, we include a lagged version of our dependent variable on the right-hand side of our equation, which is standard in ECMs. ${ }^{25}$

\section{[TABLE ONE ABOUT HERE]}

\section{Assessing the Uncertainty Hypothesis}

Table One displays our results. Overall, the fit of the model is very good, as is common with ECMs. In addition, the coefficient on the lagged dependent variable falls between 0 and -1 , indicating that the use of an ECM is appropriate. More importantly, our findings provide some support for our

\footnotetext{
${ }^{24}$ Short-term effects occur if a change in the value of an independent variable yields an immediate change in the size of the Court's docket. Conversely, long-term effects provide indication of a long-term equilibrium relationship between the independent variable and the dependent variable. If we find only short-term effects, this suggests that an ECM might not be appropriate.

${ }^{25}$ The lagged dependent variable provides two pieces of information. First, it shows how the previous level of the number of cases affects the change from that level. Second, and more importantly, it provides essential information about the rates at which the effects of other independent variables decay. These two points are essentially two sides of the same coin. Because the process is dynamic, the outcome adjusts slowly (i.e., the past is sticky), which has the implication that the effects of the independent variables decay (at a rate indicated by the coefficient on the lagged dependent variable). More generally, the outcome, being observed over time, is a temporally dynamic process, which involves partial adjustment over time (as indicated by the coefficient on the lagged dependent variable) and not immediate, complete adjustment to equilibria given by the set of explanatory-variable levels.
} 
hypotheses and show that the cert process, with the discretion it gives justices, provides the opportunity for strategic behavior with respect to the size of the docket.

Starting with the Uncertainty Hypothesis, we find that Stable Winning Coalition has a positive and significant effect on docket size, indicating that over the short run, an increase in the coalition's certainty that it will win leads to an increase in the number of cases it places on the docket. This finding also lends support to the argument, made by many authors (e.g., Caldeira, Wright, and Zorn 1999), that justices are likely to be wary of hearing cases when they are uncertain of the outcome. Our results show that a ten percent increase in the proportion of cases won by this coalition corresponds to an immediate increase in the Court's caseload of 4.2 cases. $^{26}$

Although the results for Stable Winning Coalition furnish evidence that internal considerations and uncertainty affect docket size in predictable and systematic ways, we find no support for our other measures of internal strategic behavior. Neither Split Decisions nor Ideologically Disconnected Coalitions had the expected effect; nor did several other variables that could be seen as capturing the effect of internal uncertainty. ${ }^{27}$ While there is some support for the Uncertainty Hypothesis due to the effect of Stable Winning Coalition, overall evidence for this hypothesis is best described as mixed.

\footnotetext{
${ }^{26}$ The lack of significance for the long-run variable shows that there is no relationship between the level of the stability of the winning coalition and docket size. That is, the short-term variable captures the transitory relationship, but the result for the long-term variable indicates that there is no further disequilibrium to be corrected over time. Overall, then, although the level of Stable Winning Coalition does not affect the overall docket size, a change in the stability of the winning coalition does.

${ }^{27}$ We examined some other reasonable indicators of uncertainty, like the length of time that a natural Court has been in existence (under the idea that this produces less uncertainty over time), the standard deviation of the ideologies of the justices, and the distance between the most liberal and the most conservative justices in each Court. None of these produced the expected effect. It is possible that split decisions might matter in some policy areas, but not others; or that some types of split decisions foster uncertainty while others do not. Investigation of these sorts of
} 


\section{Assessing the Separation of Powers Hypothesis}

Moving to the external considerations outlined in our second hypothesis, we find substantial evidence that the Court considers the preferences of other institutions when deciding on its caseload. More specifically, we argued that the cert process allows discretion and the opportunity for strategic behavior - not by having justices and clerks examine each specific case to determine whether Congress might object, but by leading to greater caution when the other branches are more distant. The results for Supreme Court Outlier demonstrate the expected negative and statistically significant effects predicted by the Separation of Powers Hypothesis, both in the short term and the long term.

Recall that this variable is set equal to one when the Court's preferences (as measured by the median member of the Court) fall outside of the Pareto set for the House, Senate, and president. Our results indicate that when the Court is an ideological outlier vis-à-vis these other institutions, it hears fewer cases. ${ }^{28}$ The significance of the short-term variable indicates that the transition from the Court not being an outlier to being an outlier creates momentum for the Court to take fewer cases - roughly eleven

questions holds promise, but entails an individual-level analysis of decisions that puts it beyond the reach of this paper.

${ }^{28}$ A counter-argument might hold that a more distant Congress or president may generate a higher number of laws that the Court finds objectionable. If true, then a situation in which the Court is ideologically distant from one of these branches might produce a higher number of cases that the Court considers. We tested this by including three variables - the absolute values of the distances from the median justice to the president, the median member of the House, and the median member of the Senate - in our model, both with and without Supreme Court Outlier. In doing so, we find some, albeit limited, support for this counter-argument, with the distance between the Court and Senate medians significantly associated with only a long-term decrease in docket size $(\mathrm{p}<.05$ without Supreme Court Outlier included; $\mathrm{p}<.10$ with it included), and the distance between the Court and president significantly connected with only a short-term decrease in docket size ( $\mathrm{p}<.05$ without Supreme Court Outlier included; $\mathrm{p}<.10$ with it included). We observe no such effect for the House. In addition, the Supreme Court Outlier measure remains significant and negative. 
fewer cases, according to our results. In addition, the significance of the long-term variable shows that there is an effect between the level of our independent variable (i.e., whether the Court is an outlier) and the overall size of the docket. ${ }^{29}$ Hence, even if the Court sometimes shifts to other types of cases, it is more selective overall when its views are at odds with the preferences of the elected branches. ${ }^{30}$

Our study thus joins previous studies that have found evidence of the Court acting in a strategic manner relative to other political institutions on an individual or aggregate level (e.g., Bailey and Maltzman 2011; Clark 2011; Epstein and Knight 1998; Harvey and Friedman 2006, 2009; McGuire 2004). Other studies, however, have produced mixed results, or have found no evidence at all (e.g., Owens 2010; Sala and Spriggs 2004; Segal, Westerland, and Lindquist 2011). While scholars need to continue exploring the effect of external institutions on the Court's actions, our results speak to this debate by providing evidence that the Court considers the preferences of other institutions when it decides the size of its docket in aggregate, and more generally by showing that separation-of-powers concerns influence the Court's aggregate level actions (e.g., Epstein and Knight 1998; Epstein, Segal and Victor 2002).

\section{Control Variables}

Although our primary interest is in the effect of the strategic variables discussed above, our tests reveal some interesting results for our control variables. We find limited support for three of our controls

\footnotetext{
${ }^{29} \mathrm{We}$ also tested our argument using a dynamic, but non-ECM, approach. Results are essentially the same as those presented here. However, because Supreme Court Outlier shows evidence of a long-run equilibrium relationship with the size of the docket, we present the ECM results.

${ }^{30}$ The coefficient on our lagged dependent variable allows us to more precisely estimate the nature of the short- and long-term influences of Supreme Court Outlier. When this variable equals one, it produces an immediate decrease of 10.9 cases. However, the long-run effect indicates that it also disrupts the long-term equilibrium between the two variables. The long-run response is that the presence of an outlier decreases the number of cases by a total of 12.6, with this total spread out over future time periods with a decay of 54\% (based on the coefficient on the lagged number of cases) per period.
} 
as short-term effects, with findings that are best viewed as suggestive, since each of these three controls falls just short of the standard level of $\mathrm{p}<.05$ (i.e., all three meet the more relaxed standard of $\mathrm{p}<.10$ ). First, the number of petitions filed by the Solicitor General is associated with an increase in docket size, with three additional petitions in a term increasing the size of the docket by approximately one case in the short-term. Second, we find that the 1988 law led to a decrease in docket size, producing a transitory decrease of approximately 21 cases per term. ${ }^{31}$ Finally, the results for our Blackmun/Join-3 variable indicate that Blackmun's support for the Join-3 approach yielded an increase of 12 cases per term. ${ }^{32}$

At the same time, we find no support for our other control variables. Unlike Owens and Simon (2012), we find no effect for the difference between the Supreme Court and appellate courts, with neither Judicial Agreement nor Supreme-Appellate Court Distance producing the predicted effects. Additionally, the Court's capacity, as measured by Institutionalization, has no effect on docket size. Moreover, the Court also does not appear to respond to the number of court-curbing bills that were introduced in Congress, nor does it appear to respond to the number of major laws on the federal level.

\section{Additional Checks}

We also examined many other variables that have been suggested as potential influences, even though they are not identified or investigated as frequently as the controls included in Table One. ${ }^{33}$

\footnotetext{
${ }^{31}$ As we noted earlier, the dummy variable for the 1988 law is a blunt measure and is not theoretically motivated. But because so many other scholars have made claims for the effect of this law, we have included it in our model. We also examined whether the 1988 law created a situation in which short-run effects began to play a larger role, and did so by interacting the post-1988 dummy with our theoretical variables and by examining results before and after the passage of this law. Doing this produced no support for the idea that short-term factors were enhanced after 1988.

${ }^{32}$ Since there is some evidence that Justice White also favored a join-3 approach, we ran a model that included a dummy variable for White. This variable was not significant, and did not affect our main theoretical results.

${ }^{33}$ We encourage caution in interpreting the findings for the various control variables discussed throughout this section. More specifically, some of these variables depend on individual-level arguments, yet we have aggregate-
} 
Among others, we found that the following control variables had no effect on docket size: the number of cases following from original jurisdiction (Sternberg 2008); the number of in forma pauperis petitions; appellate experience (Coyle 2007); the number of liberal justices on the Court (Hellman 1996); the number of new issues that the Court considers when compared to the previous term (Pacelle 1991) ${ }^{34}$ and a measure of judicial activism. ${ }^{35}$ Another variable - the number of justices in the cert pool - was (surprisingly) significant in the opposite direction. ${ }^{36}$ In the overwhelming majority of instances, the inclusion of these other variables had little or no effect on our main variables of interest.

level data. This is not a problem for our theoretical variables (or the controls in Table One), since for one strategic claim, we have presented an argument about how the individual incentives aggregate, while for the other the argument itself is at the aggregate level.

${ }^{34} \mathrm{We}$ also used the number of new issues that the Court considers between $\mathrm{t}-2$ and $\mathrm{t}-1$, between $\mathrm{t}-3$ and $\mathrm{t}-2$, and finally, between t-4 and t-3 in separate models, and uncovered no statistically significant effects for this variable. We used these varying lags to investigate the possibility that it takes time for additional cases to percolate to the Court that are related to new issues that the Court heard in previous terms.

${ }^{35}$ Judicial activism is a notoriously slippery concept (e.g., Lindquist and Cross 2009). Since there is no definitive measure, we adopt one employed by Yale law professor Paul Gerwitz and former Justice Stevens clerk Chad Golder (2005; see also Ringhand 2007): we take all cases in which the federal government is a party and calculate the percentage of these cases in which the Court decided against the government. This is consistent with one of the primary dimensions of judicial activism that Canon (1983) identifies, namely, that activism exists when the courts rule against policies that were created and are supported by majoritarian institutions.

${ }^{36}$ As we noted earlier, we did not expect the creation of the cert pool to produce a reduction in docket size, since the greatest effect of the pool is to more efficiently eliminate cases that would never get on the docket anyway (Palmer 2001; Perry 1991). Our results are consistent with arguments made by Cordray and Cordray (2001) and with Owens and Simon's (2012) findings. A dummy for the presence of the cert pool, rather than the number of justices participating, similarly did not demonstrate a reduction in docket size. Notably, the effects for Supreme Court Outlier were stronger when we included this dummy variable than they are in the results reported here. 
In addition, at least one participant - Justice Souter - has pointed toward the homogeneity of the lower courts as an explanation for the decrease in recent years (Stras 2010), although some law scholars remain skeptical of this claim. Cordray and Cordray (2001), for example, point out that even with increasing homogeneity, there are still hundreds of splits at the appellate level each year, leaving the justices with no shortage of controversies to tackle. Nonetheless, we created a new variable to assess Justice Souter's claims. ${ }^{37}$ In doing so, we find that the homogeneity of the lower courts did not affect docket size in either the short or long-term.

Finally, Stras (2010) used Justice Blackmun's notes to demonstrate that justices were replaced by new justices during the late 1980s and early 1990s who consistently voted to hear fewer cases. Although we do not have this sort of individual-level data over the entire period, and while this factor does not account for why these new justices behaved in this manner, we can account for the number of new justices in each Court. When we do so, we find that this variable has no consistent effect on docket size, and its inclusion has little effect on our other results. ${ }^{38}$

\section{Conclusion}

The content and size of Court's docket says much about the place and role of the Court in the American political system (Owens and Simon 2012). At a minimum, when the docket is larger, the Court has the opportunity to play more of a policymaking role. And when it is smaller, it removes the Court from addressing important policy and political questions.

Some scholars have suggested that change in docket size is not "a result of a conscious and collective or strategic decision" (O'Brien 2005, 134). Our findings, though, provide evidence that justices act strategically when setting the docket. In particular, we find strong evidence that separation-of-powers

\footnotetext{
${ }^{37}$ We used the following equation to measure the homogeneity of the lower courts: Homogeneity= 150-Percentage of Appellate Judges from the Republican Partyl. The presence of this variable does not affect the signs or significance patterns of our main variables of interest. Using instead the change in this variable from t-2 to t-1 produces no significant findings and has no effect on our primary variables.

${ }^{38}$ The only change is that the long-term effect for Supreme Court Outlier drops to the $\mathrm{p}<.10$ level of significance.
} 
considerations matter, and weaker evidence that internal uncertainty has a significant effect. As justices become more certain about the likely choices of their colleagues, and more confident that their decisions will not trigger negative reactions from elected officials, they hear more cases; and as they become less certain about their colleagues and more worried about the reactions of the other branches, they hear fewer. Thus, we provide direct evidence that the size of the agenda in one year is more than just a function of the docket in prior years. Rather, the size of the Court's docket is a function of the ideological location of the Court, relative to other branches, and (to a lesser degree) the preferences of those who sit on the Court.

Beyond providing support for our hypotheses, the results also yield insights regarding potential causal variables identified by other scholars and observers, such as the number of petitions that the Solicitor General submitted. Further, our analysis focuses on docket size over time, and not just on the recent decrease (which is the focus of most legal scholarship on this question). In doing so, it provides more complete evidence regarding the effect of strategic considerations and other factors.

Some questions, of course, remain unanswered. Since individual-level data on cert decisions is not available over the entire time frame we examine, we cannot assess how individual replacement of one justice by another influences docket size. It seems possible that this notion of replacement is a potential cause of changes in the docket size (e.g., Stras 2010), but this finding then leads to questions about why new justices have different preferences regarding the Court's workload than the justices they are replacing. We also cannot assess how litigant behavior affects the likelihood that a particular case comprises the docket. Such behavior certainly influences whether a particular case becomes a part of the docket (e.g., Mak, Sidman, and Sommer 2013), and could affect the overall caseload.

Second, we do not, and cannot, explore all possible explanations that have been offered to explain the diminishing docket. For example, we do not explore the effects of the median age of Supreme Court justices, the median length of tenure on the Court, specific facets of the ways in which different Chief Justices have led the Court, or the differences in the length of total opinions for cases in each term. That said, we have considered many of the most common explanations that scholars have offered to explain variance in docket size. Given the robustness of our results to these many alternative explanations, we 
have no reason to believe that the results would not continue to hold, even after including other explanations.

Finally, we do not explore the consequences of a diminishing docket (e.g., Lazarus 2009). Does docket size affect justices' behavior and public perceptions of the Court? How might it influence the scope and magnitude of the Court's power? In other words, do we need to see an increase in docket size to conclude that the Court "matters?" Our analysis provides a useful springboard for future studies to investigate these and other topics, as it shows that docket size varies over time, and that this variation has a systematic component; that strategic considerations, both internal and external, come into play in determining the size of the docket; and that some (although not all) of the other factors that various observers have posited as being influential do indeed have the predicted effects on docket size. 


\section{References}

Bailey, Michael A. 2013. "Is Today’s Court the Most Conservative in Sixty Years? Challenges and Opportunities in Measuring Judicial Preferences.” Journal of Politics 75(3): 821-834.

Bailey, Michael A. and Forrest Maltzman 2011. The Constrained Court: Law, Politics, and the Decisions Justices Make. Princeton: Princeton University Press.

Bailey, Michael A., Forrest Maltzman and Charles R. Shipan 2011. “The Amorphous Relationship Between Congress and the Courts.” In The Oxford Handbook of Congress, eds. George. C. Edwards, Frances. E. Lee and Eric Schickler. New York: Oxford University Press, 834-861.

Baker, Thomas E. and Douglas D. MacFarland 1987. “The Need For a New National Court.” Harvard Law Review 100: 1400-1416.

Barnes, Robert 2007. “Justices Continue Trend of Hearing Fewer Cases.” The Washington Post, January 7, 2007.

Baum, Lawrence 1977. "Policy Goals in Judicial Gatekeeping: A Proximity Model of Discretionary Jurisdiction.” American Journal of Political Science 21(1): 13-36.

Black, Ryan C. and Ryan J. Owens 2009. “Agenda Setting in the Supreme Court: The Collision of Policy and Jurisprudence.” Journal of Politics 71(3): 1062-1075.

Black, Ryan C. and Ryan J. Owens 2012. “Looking Back to Move Forward: Quantifying Policy Predictions in Political Decision Making.” American Journal of Political Science 56(4): 802-816.

Blackstone, Bethany 2013. “An Analysis of Policy-Based Congressional Responses to the U.S. Supreme Court's Constitutional Decisions." Law and Society Review 47(1): 199-228.

Brennan, William J., Jr. 1973. “The National Court of Appeals: Another Dissent.” The University of Chicago Law Review 40(3): 473-485.

Brenner, Saul and John F. Krol 1989. "Strategies in Certiorari Voting on the United States Supreme Court.” Journal of Politics 51(4): 828-840.

Caldeira, Gregory, John Wright and Christopher Zorn 1999. "Sophisticated Voting and Gatekeeping on the U.S. Supreme Court.” Journal of Law, Economics and Organization 15(3): 549-572. 
Canon, Bradley C. 1983. "Defining the Dimensions of Judicial Activism.” Judicature 66(6): 236-247.

Chandler, Adam and Jennifer Harris 2010. "Important Questions of Federal Law: An Empirical Survey of Possibly Explanations for the Supreme Court's Declining Docket.” Presented at the Conference on Important Questions of Federal Law: Assessing the Supreme Court's Case Selection Process, Yale Law School, March 23.

Clark, Tom S. 2009. “The Separation of Powers, Court Curbing, and Judicial Legitimacy.” American Journal of Political Science 53(4): 971-989.

Clark, Tom S. 2011. The Limits of Judicial Independence. New York: Cambridge University Press. Cordray, Margaret Meriwether and Richard Cordray 2001. "The Supreme Court's Plenary Docket." Washington and Lee Law Review 58(3): 737-794.

Coyle, Marcia 2007. "Despite Docket Drop, Justices Face Packed Homestretch.” The National Law Journal, June 6.

Dahl, Robert A. 1957. "Decision-Making in a Democracy: The Supreme Court as a National PolicyMaker.” Journal of Public Law 6(1): 279-295.

De Boef, Suzanna 2001. “Modeling Equilibrium Relationships: Error Correction Models with Strongly Autoregressive Data.” Political Analysis 9(1): 78-94.

De Boef, Suzanna, and Luke Keele 2008. “Taking Time Seriously.” American Journal of Political Science 52(1): 184-200.

Edelman, Paul H., David E. Klein, and Stefanie A. Lindquist 2008. "Measuring Deviations from Expected Voting Patterns on Collegial Courts.” Journal of Empirical Legal Studies 5(4): 819852.

Epstein, Lee, Andrew D. Martin, Jeffrey A. Segal, and Chad Westerland 2007. “The Judicial Common Space." Journal of Law, Economics and Organization 23(2): 303-325.

Epstein, Lee, and Jack Knight 2008. The Choices Justices Make. Washington, DC: CQ Press. Epstein, Lee, Jeffery A. Segal, Harold J. Spaeth and Thomas G. Walker 2007. The Supreme Court Compendium: Data, Decisions and Development. Washington, DC: CQ Press. 
Epstein, Lee, Jeffrey A. Segal, and Jennifer Nicoll Victor 2002. "Dynamic Agenda-Setting on the United States Supreme Court: An Empirical Assessment.” Harvard Journal on Legislation 39(2002): 395-433.

Ferejohn, John, Frances Rosenbluth, and Charles R. Shipan. 2007. “Comparative Judicial Politics.” 2007. In The Oxford Handbook of Comparative Politics, eds. Carles Boix and Susan C. Stokes. Oxford University Press.

Ferejohn, John, and Charles R. Shipan 1990. “Congressional Influence on Bureaucracy.” Journal of Law, Economics, and Organization 6(1):1-20.

Greenhouse, Linda 2006. "Dwindling Docket Mystifies Supreme Court.” The New York Times, New York, NY, December 7, Page A1.

Gryski, Gerard and Ronald Zuk 2011. “Attributes of U.S. Federal Judges Database.” Available at http://www.cas.sc.edu/poli/juri/attributes.htm (June 22, 2015).

Harvey, Anna and Barry Friedman 2006. "Pulling Punches: Congressional Constraints on the Supreme Court's Constitutional Rulings, 1987-2000.” Legislative Studies Quarterly 31(4): 533-562.

Harvey, Anna and Barry Friedman 2009. "Ducking Trouble: Congressionally-Induced Selection Bias in the Supreme Court's Agenda.” Journal of Politics 71(2): 574-592.

Hellman, Arthur D. 1996. "The Shrunken Docket of the Rehnquist Court.” The Supreme Court Review 1996(1996): 403-438.

Hendershot, Marcus E., Mark S. Hurwitz, Drew Noble Lanier, and Richard L. Pacelle, Jr. 2013. "Dissensual Decision Making: Revisiting the Demise of Consensual Norms within the U.S. Supreme Court.” Political Research Quarterly 66(2): 467-481.

Keele, Luke, and Nathan P. Kelly 2006. "Dynamic Models for Dynamic Theories: The Ins and Outs of Lagged Dependent Variables.” Political Analysis 14(2): 186-2005.

Lazarus, Richard J. 2009. “Docket Capture at the High Court.” Yale Law Journal 119(89): 89-97. 
Mak, Maxwell, Andrew Sidman, and Udi Sommer 2013. "Is Certiorari Contingent on Litigant Behavior? Petitioners' Role in Strategic Auditing.” Journal of Empirical Legal Studies 10(1): 54-75.

Maltzman, Forrest, James F. Spriggs, II, and Paul J. Wahlbeck 2000. Crafting Law on the Supreme Court: The Collegial Game. New York: Cambridge University Press.

Mayhew, David R 2005. Divided We Govern: Party Control, Lawmaking, and Investigations. New Haven: Yale University Press.

McGuire, Kevin T. 2004. “The Institutionalization of the U.S. Supreme Court.” Political Analysis 12(2): 128-142.

Murphy, Walter F. 1964. Elements of Judicial Strategy. Chicago: University of Chicago Press.

O’Brien, David M. 1997a. “The Rehnquist Court's Shrinking Plenary Docket.” Judicature 81(58): 58-65.

O’Brien, David M. 1997b. "Join-3 Votes, the Rule of Four, the Cert. Pool, and the Supreme Court's Shrinking Plenary Docket.” Journal of Law and Politics 13(Fall): 779-808.

O’Brien, David M. 2005. “Diminished Plenary Docket - A Legacy of the Rehnquist Court.” Judicature 89(November/December): 134-137, 182.

Owens, Ryan J. 2010. “The Separation of Powers and Supreme Court Agenda Setting.” American Journal of Political Science 54(2): 412-427.

Owens, Ryan J., and David A. Simon 2012. "Explaining the Supreme Court's Shrinking Docket." William and Mary Law Review 53(4): 1219-1285.

Pacelle, Richard L. 1991. The Transformation of the Supreme Court's Agenda: From the New Deal to the Reagan Administration. Boulder: Westview Press.

Palmer, Barbara 2001. “The 'Bermuda Triangle?' The Cert Pool and its Influence over the Supreme Court's Agenda." Constitutional Commentary 18(1): 105-120.

Palmer, Jan 1982. “An Econometric Analysis of the U.S. Supreme Court's Certiorari Decisions.” Public Choice 39(3): 387-398.

Perry, H.W. 1991. Deciding to Decide: Agenda Setting in the United States Supreme Court. Cambridge: Harvard University Press. 
Sala, Brian and James F. Spriggs 2004. "Designing Tests of the Supreme Court and the Separation of Powers.” Political Research Quarterly 57(2): 197-208.

Scalia, Antonin 1989. "The Rule of Law as a Law of Rules.” The University of Chicago Law Review 56(4): $1175-1188$.

Segal, Jeffrey A. 1997. "Separation-of-Powers Games in the Positive Theory of Congress and Courts." American Political Science Review 91(1): 28-45.

Segal, Jeffrey A., Chad Westerland and Stefanie A. Lindquist 2011. "Congress, the Supreme Court, and Judicial Review: Testing a Constitutional Separation of Powers Model.” American Journal of Political Science 55(1): 89-104.

Segal, Jeffrey A. and Harold J. Spaeth 2002. The Supreme Court and the Attitudinal Model Revisited. New York: Cambridge University Press.

Shipan, Charles R. 1997. Designing Judicial Review: Interest Groups, Congress, and Communications Policy. Ann Arbor: University of Michigan Press.

Shipan, Charles R. 2000. “The Legislative Design of Judicial Review: A Formal Analysis.” 2000. Journal of Theoretical Politics 12(3): 269-304.

Songer, Donald R. 1979. “Concern for Policy Outputs as a Cue for Supreme Court Decisions on Certiorari." Journal of Politics 41(4): 1185-1194.

Spaeth, Harold J. 2015. “The Original United States Supreme Court Judicial Database, 1946-2013 Terms.” Available at http://supremecourtdatabase.org (January 26, 2015).

Starr, Kenneth W. 2005-2006. "The Supreme Court and Its Shrinking Docket: The Ghost of William Howard Taft.” Minnesota Law Review 90(5): 1363-1385.

Stern, Robert L., Eugene Gressman, Stephen M. Shapiro, and Kenneth S. Geller 2002. Supreme Court Practice. $8^{\text {th }}$ Ed. Washington, D.C.: CQ Press.

Sternberg, Jonathan 2008. "Deciding Not to Decide: The Judiciary Act of 1925 and the Discretionary Court." Journal of Supreme Court History 33(1): 1-16. 
Stras, David 2010. “The Supreme Court's Declining Plenary Docket: A Membership-Based Explanation.” Constitutional Commentary 27(1): 151-161.

United States Attorney General. Annual Report of the Attorney General. Washington, D.C.: Government Printing Office, Various Years.

Von Drehle, David 2007. “Inside The Incredibly Shrinking Role Of the Supreme Court. And Why John Roberts Is O.K. with that." Time. October 22.

Whittington, Keith 2007. Political Foundations of Judicial Supremacy: The Presidency, the Supreme Court, and Constitutional Leadership in U.S. History. Princeton: Princeton University Press. 
Figure One: United States Supreme Court's Docket Size, 1946-2009.

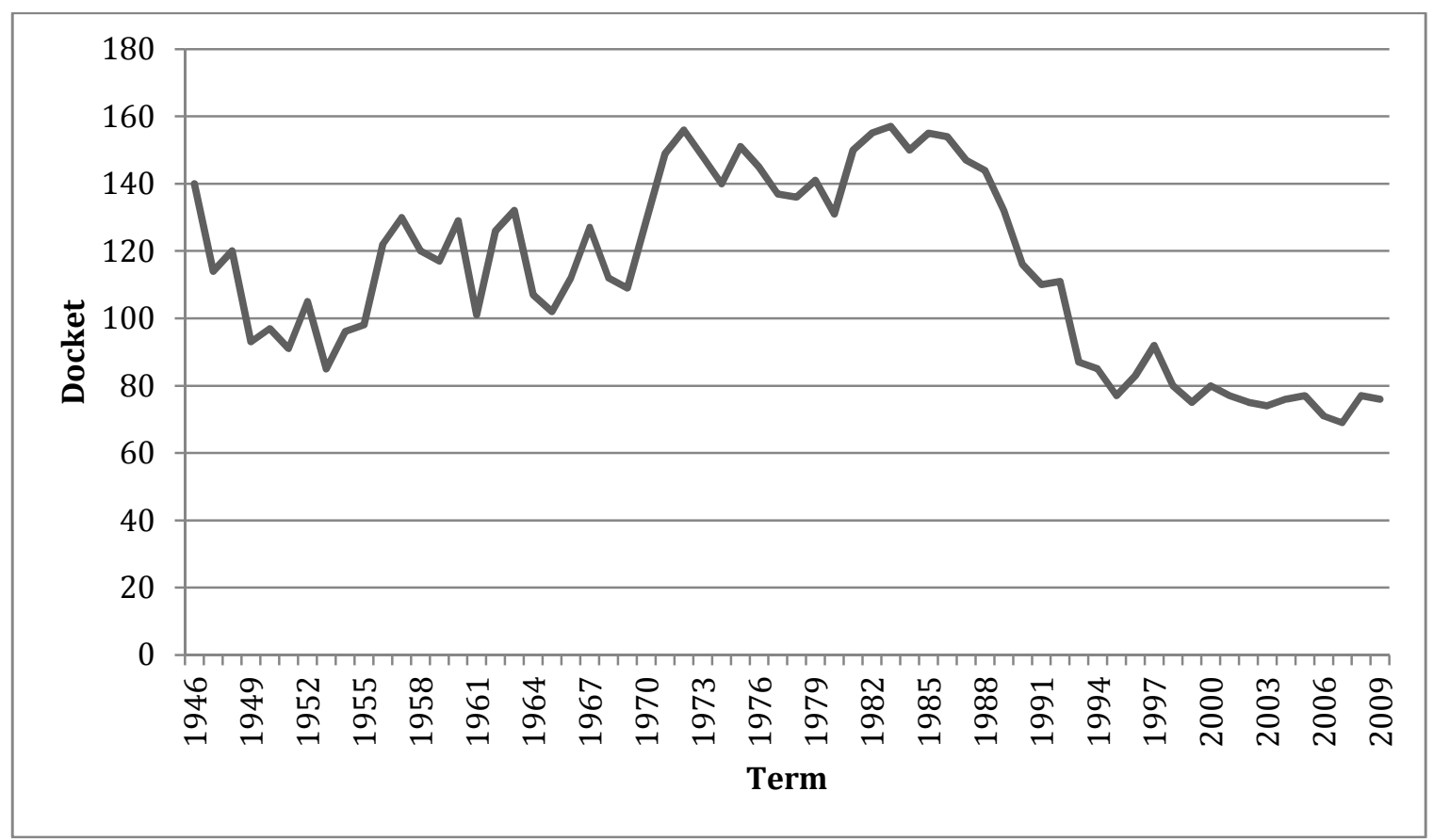

Sources: The Supreme Court Compendium and the Chief Justice's Annual Report 
Figure Two: Cases Submitted to the United States Supreme Court for Review, 1946-2009.

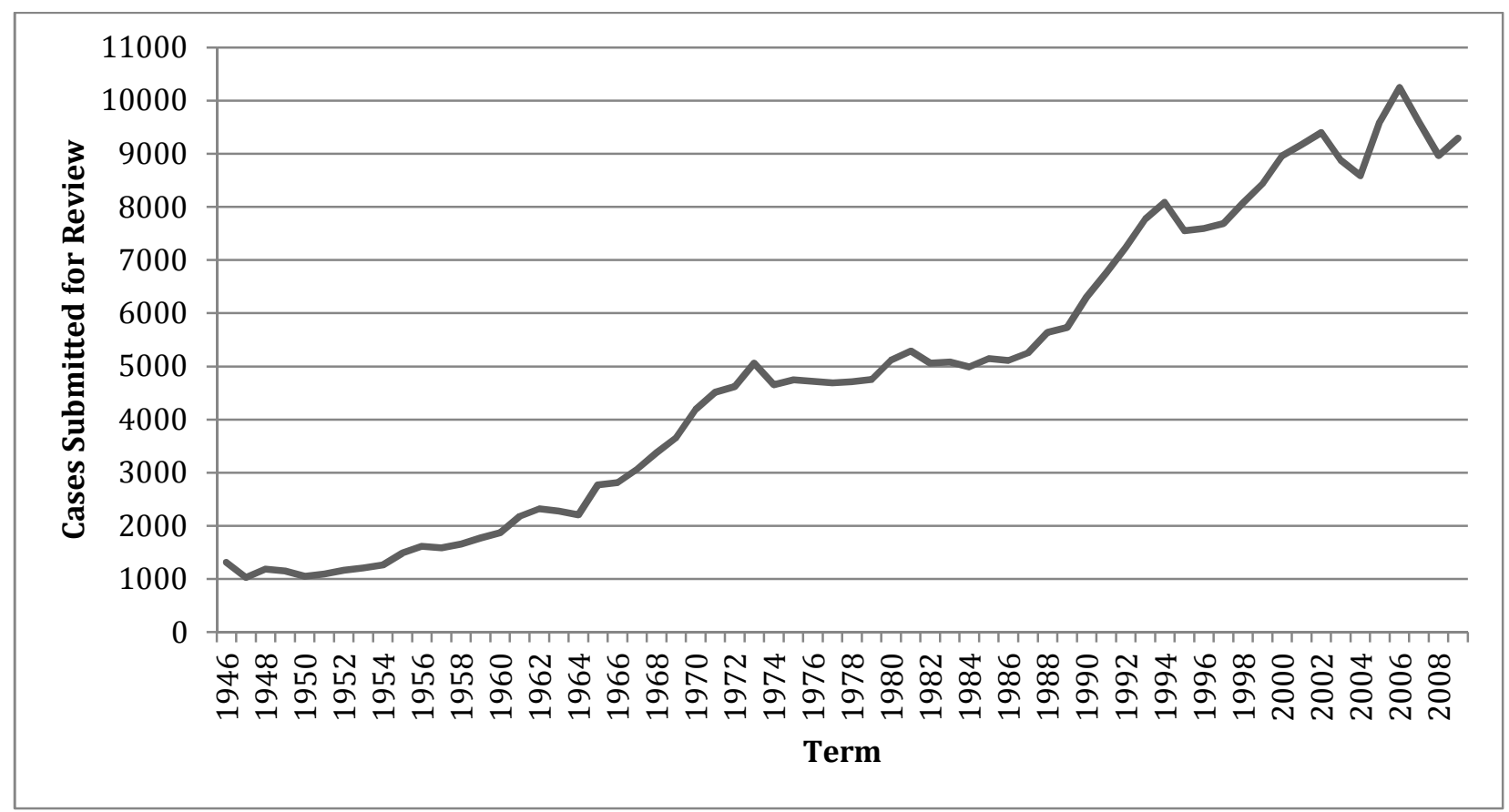

Source: The Original United States Supreme Court Database 
Table One: Variation in the Supreme Court's Docket Between 1946 and 2005.

\begin{tabular}{|c|c|c|c|}
\hline & $\begin{array}{l}\text { Theoretical } \\
\text { Expectation }\end{array}$ & Short-term effects & Long-term effects \\
\hline \multicolumn{4}{|l|}{ Uncertainty Hypothesis } \\
\hline Stable Winning Coalition & + & $\begin{array}{l}.42 * \\
(.24)\end{array}$ & $\begin{array}{l}-.03 \\
(.34) \\
\end{array}$ \\
\hline Split Decisions & - & $\begin{array}{l}.88^{\wedge} \\
(.48)\end{array}$ & $\begin{array}{l}.48 \\
(.60)\end{array}$ \\
\hline Ideologically Disconnected Coalitions & - & $\begin{array}{c}.29 \\
(.23) \\
\end{array}$ & $\begin{array}{l}.53^{\wedge} \\
(.31)\end{array}$ \\
\hline \multicolumn{4}{|l|}{ Separation of Powers Hypotheses } \\
\hline Supreme Court Outlier & - & $\begin{array}{c}-10.92 * \\
(4.57) \\
\end{array}$ & $\begin{array}{l}-6.81^{*} \\
(3.95) \\
\end{array}$ \\
\hline \multicolumn{4}{|l|}{ Controls } \\
\hline Major Laws & + & $\begin{array}{c}.08 \\
(.51) \\
\end{array}$ & $\begin{array}{c}.02 \\
(.35)\end{array}$ \\
\hline Judicial Agreement & - & $\begin{array}{l}13.08^{\wedge} \\
(4.68)\end{array}$ & $\begin{array}{c}-.69 \\
(4.38)\end{array}$ \\
\hline Supreme-Appellate Court Distance & + & $\begin{array}{c}13.33 \\
(23.31)\end{array}$ & $\begin{array}{l}-10.44 \\
(20.27)\end{array}$ \\
\hline Post-1988 & - & $\begin{array}{l}-20.92 \\
(13.78)\end{array}$ & $\begin{array}{c}-9.27 \\
(14.77)\end{array}$ \\
\hline Institutionalization & + & $\begin{array}{r}27.88 \\
(42.04) \\
\end{array}$ & $\begin{array}{c}17.19 \\
(33.59) \\
\end{array}$ \\
\hline Blackmun/Join-3 & + & $\begin{array}{l}12.06 \\
(8.40)\end{array}$ & $\begin{array}{c}3.65 \\
(7.05) \\
\end{array}$ \\
\hline Court Curbing & - & $\begin{array}{c}48.48 \\
(87.18)\end{array}$ & $\begin{array}{c}61.40 \\
(62.15)\end{array}$ \\
\hline Solicitor General Petitions & + & $\begin{array}{c}.33 \\
(.24) \\
\end{array}$ & $\begin{array}{c}.43 \\
(.40) \\
\end{array}$ \\
\hline Lagged Supreme Court Docket & N/A & \multicolumn{2}{|c|}{$\begin{array}{c}-.54 * * \\
(.20)\end{array}$} \\
\hline Constant & \multicolumn{3}{|c|}{$\begin{array}{l}-35.60 \\
(44.90)\end{array}$} \\
\hline $\mathrm{N}$ & \multicolumn{3}{|c|}{54} \\
\hline Adjusted R-Squared & \multicolumn{3}{|c|}{.742} \\
\hline Mean Squared Error & \multicolumn{3}{|c|}{8.32} \\
\hline F-Test & \multicolumn{3}{|c|}{3.23} \\
\hline Prob $>\mathrm{F}$ & \multicolumn{3}{|c|}{.0016} \\
\hline
\end{tabular}


Appendix A: Summary Statistics for Docket Variables

\begin{tabular}{|c|c|c|c|c|c|}
\hline Variable & Source & Mean & $\frac{\text { Standard }}{\text { Deviation }}$ & Minimum & Maximum \\
\hline Docket & The Original United States Supreme Court Database & 116.12 & 26.52 & 74 & 157 \\
\hline Stable Winning Coalition & The Original United States Supreme Court Database & 57.60 & 9.24 & 32.97 & 73.49 \\
\hline Split Decisions & The Original United States Supreme Court Database & 15.73 & 7.16 & 0 & 30 \\
\hline $\begin{array}{c}\text { Ideologically } \\
\text { Disconnected Coalitions }\end{array}$ & The Original United States Supreme Court Database & 67.55 & 14.04 & 37.33 & 96.77 \\
\hline Supreme Court Outlier & Bailey (2013) & .31 & .47 & 0 & 1 \\
\hline Major Laws & Mayhew (2005) & 19.78 & 5.27 & 11 & 33 \\
\hline Judicial Agreement & $\begin{array}{l}\text { Supreme Court Ideology: Epstein, Martin, Segal and } \\
\text { Westerland (2007) } \\
\text { Partisan Composition of the Lower Courts: Gryski and Zuk } \\
\text { (2004) }\end{array}$ & .57 & .50 & 0 & 1 \\
\hline $\begin{array}{l}\text { Supreme-Appellate } \\
\text { Court Distance }\end{array}$ & Epstein, Martin, Segal and Westerland (2007) & .16 & .10 & .004 & .38 \\
\hline Post-1988 & N/A & .28 & .45 & 0 & 1 \\
\hline Institutionalization & McGuire (2004) & 1.19 & .11 & .92 & 1.37 \\
\hline Blackmun/Join-3 & N/A & .42 & .50 & 0 & 1 \\
\hline Court Curbing & Clark $(2009,2011)$ & .45 & .10 & .12 & .50 \\
\hline $\begin{array}{l}\text { Solicitor General } \\
\text { petitions }\end{array}$ & Annual Report of the Attorney General & 29.27 & 11.53 & 9 & 61 \\
\hline
\end{tabular}

